\title{
Data report: total cell counts and qPCR abundance of Archaea and Bacteria in shallow subsurface marine sediments of North Pond: gravity cores collected during site survey cruise prior to IODP Expedition $336^{1}$
}

\author{
Anja Breuker ${ }^{2}$ and Axel Schippers ${ }^{2}$
}

\section{Chapter contents}

Introduction $\ldots \ldots \ldots \ldots \ldots \ldots \ldots \ldots$

Materials and methods............. 1

Results and conclusions............

Acknowledgments...............

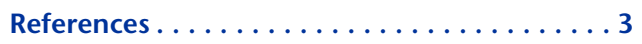

Figures..............

\section{Introduction}

The total number of prokaryotes in deeply buried marine sediments decreases with sediment depth and varies over orders of magnitude in different areas of the ocean. It is mainly controlled by the content of organic carbon in the sediment as the microbial substrate (Parkes et al., 1994; D'Hondt et al., 2004; Schippers et al., 2005, 2012; Edwards et al., 2012; Kallmeyer et al., 2012; Lomstein et al., 2012; Hoehler and Jørgensen, 2013). Organic-lean, oligotrophic, and oxic sediments of the Pacific host oxygen-respiring prokaryotes (Røy et al., 2012). Specific archaeal communities for sediments with different trophic states could be detected (Durbin and Teske, 2012). An open question is if Bacteria or Archaea dominate in oligotrophic sediments as previously discussed for eutrophic sediments based on quantitative polymerase chain reaction (qPCR) analysis (Schippers et al., 2005, 2012). Similar to oligotrophic Pacific sediments, oligotrophic (total organic carbon $=\sim 0.15 \% \pm 0.07 \%$ ) and oxic sediments from the North Pond area in the $7 \mathrm{~m}$.y. old western flank of the Mid-Atlantic Ridge at $23^{\circ} \mathrm{N}$ have been shown to contain molecular oxygen downhole to $>8 \mathrm{~m}$ sediment depth. Aerobic respiration likely dominates organic carbon oxidation (Ziebis et al., 2012). During a site survey cruise prior to Integrated Ocean Drilling Program (IODP) Expedition 336 to North Pond, sediment cores were collected to 8 meters below seafloor (mbsf). We sampled these cores to count total cells and determine the abundance of Bacteria and Archaea by qPCR using modified protocols.

\section{Materials and methods}

'Breuker, A., and Schippers, A., 2013. Data report: and Bacteria in shallow subsurface marine sediments of North Pond: gravity cores collected during site survey cruise prior to IODP Expedition 336. In Edwards, K.J., Bach, W., Klaus, A., and the Expedition 336 Scientists, Proc. IODP, 336: Tokyo (Integrated Ocean Drilling Program Management International, Inc.).

doi:10.2204/iodp.proc.336.201.2013

${ }^{2}$ Federal Institute for Geosciences and Natural Resources (BGR), Stilleweg 2, 30655 Hannover, Germany. Correspondence author: axel.schippers@bgr.de

\begin{abstract}
Organic-lean, oligotrophic, and oxic sediments from the North Pond area in the $7 \mathrm{~m}$.y. old western flank of the Mid-Atlantic Ridge at $23^{\circ} \mathrm{N}$ were sampled during the Expedition 336 site survey cruise with the German R/V Maria S. Merian in 2009 (MSM 11/1). Sediment cores (12 cm diameter) were successfully retrieved at six locations within the North Pond basin between 4040 and 4480 meters below sea level using gravity corers (Ziebis et al., 2012). These cores extended to 8 mbsf. Once recovered on deck, these cores were quickly cut into $1 \mathrm{~m}$ sections that were immediately carried to the cold storage room. Each $1 \mathrm{~m}$ section was subse-
\end{abstract}


quently split into half-core sections. From one half, samples for microbiological analysis were taken from the interior portion by excavation with a sterilized spoon, and the outer centimeter layer was left in the core liner to avoid contamination with seawater. In addition to the gravity cores, an additional 21 sediment samples from the shallow subsurface $(0-15 \mathrm{~cm}$ depth) were taken with the remotely operated vehicle (ROV) Jason II (push cores) during another cruise of the Maria S. Merian in 2011 (MSM 20/5).

For total cell counting, $1 \mathrm{~mL}$ of each sediment sample was preserved in $9 \mathrm{~mL}$ of $0.2 \mu \mathrm{m}$ sterile-filtered $2 \%$ formaldehyde in seawater. In the Federal Institute for Geosciences and Natural Resources (BGR) laboratory, $100 \mu \mathrm{L}$ of fixed sediment was transferred in a $2 \mathrm{~mL}$ Eppendorf tube and suspended in $1 \mathrm{~mL}$ of $0.1 \mathrm{mM}$ hydrochloric acid (after autoclaving sterile filtered) to dissolve carbonates. Samples were shaken for $5 \mathrm{~min}$ and centrifuged for $20 \mathrm{~min}$ at $16,000 \mathrm{~g}$. Afterward, $1 \mathrm{~mL}$ of supernatant was carefully removed. The pellet was suspended in $1 \mathrm{~mL}$ tris-ethylenediaminetetraacetic acid (TE) buffer and centrifuged. This step was repeated. The pellet was suspended with $900 \mu \mathrm{L}$ TE buffer followed by an ultrasonic treatment for $20 \mathrm{~s}$ (Weinbauer et al., 1998). A sample $(100 \mu \mathrm{L})$ was stained on filters with SYBR Green as described elsewhere (Lunau et al., 2005). Cells were counted using fluorescence microscopes (Weinbauer et al., 1998).

For qPCR, samples were immediately frozen at $-20^{\circ} \mathrm{C}$ after shipboard sampling. Samples were transported and stored frozen in the home laboratory. For DNA extraction from thawed samples, a published protocol for DNA extraction (Webster et al., 2003) with an additional preceding acid treatment step with iodic acid was applied to dissolve carbonates and to improve DNA extraction from cells. Kates et al. (1965) published a protocol to break ether bonds in cell walls of microorganisms using iodic acid. According to the described procedure, we applied iodic acid but in a lower concentration and a shorter incubation time $(0.1 \mathrm{~mol} / \mathrm{L}$ versus $\sim 8 \mathrm{~mol} / \mathrm{L}$ and $10 \mathrm{~min}$ versus $24 \mathrm{~h}$ ). We assumed that the modified method dissolved the carbonates and/or partially disrupted the cell walls (in particular archaeal ether bonding) but did not lyse the cells. FAST-Prep tubes without matrix were filled with $0.5 \mathrm{~g}$ of sediment and centrifuged for $30 \mathrm{~s}$ at $14,000 \mathrm{~g}$. Afterward, $1 \mathrm{~mL}$ of $0.1 \mu \mathrm{m}$ filtered $0.1 \mathrm{M}$ iodic acid was added and the pellet was suspended on a shaker for $10 \mathrm{~min}$. The tubes were heated for $10 \mathrm{~min}$ at $80^{\circ} \mathrm{C}$ and centrifuged for $15 \mathrm{~min}$ at $16,000 \mathrm{~g}$. A sample of $1 \mathrm{~mL}$ supernatant was removed, and $1 \mathrm{~mL} \mathrm{TE}$ buffer was added to the pellet and vortexed. After centrifugation, this washing step was repeated. The previously removed ma- trix was added, and the further procedure followed the protocol of the manufacturer with addition of polyadenine (Webster et al., 2003). Empty tubes were used as a negative control. Extracted DNA was amplified in triplicate by qPCR using an ABI Prism 7000 (Applied Biosystems). Published assays for the quantification of the $16 \mathrm{~S}$ rRNA gene copy numbers of Archaea (Takai and Horikoshi, 2000) and Bacteria (Nadkarni et al., 2002) were applied. 16S rRNA gene copy numbers were converted to cell numbers using conversion factors of 1.5 for Archaea and 4.1 for Bacteria, as previously done (Schippers et al., 2005).

The reliability of our new protocols was tested in spiking experiments in which known numbers of distinct organisms were added to a sediment sample and the recovery of cells was determined. Different numbers of cells of gram-negative (Escherichia coli), and gram-positive (Bacillus subtilis) Bacteria and Archaea (Methanohalobium evestigatum), were suspended in sediment samples, and the recovery of the cells was determined (Fig. F1). The new procedure considerably improved cell number recovery. In addition, the acid dissolution of carbonates was confirmed by scanning electron microscopy of samples before and after acid treatment (Fig. F2).

\section{Results and conclusions}

In agreement with published data for other oligotrophic sediments (Kallmeyer et al., 2012), our data show overall low cell numbers decreasing with sediment depth (Fig. F3). An average 1-2 orders of magnitude higher abundance of Archaea than of Bacteria was found, in contrast to the previously studied, rather organic carbon-rich sediments with a much higher qPCR abundance of Bacteria (Schippers et al., 2005,2012 ). The near-surface sediment samples up to $15 \mathrm{~cm}$ depth showed mean values (and standard deviation) of $2.2 \times 10^{8}\left(1.9 \times 10^{8}\right)$ cells $/ \mathrm{mL}$ for Archaea and $1.5 \times 10^{7}\left(1.8 \times 10^{7}\right)$ cells $/ \mathrm{mL}$ for Bacteria. These qPCR data reflect the dominance of Archaea even at the sediment surface. As an explanation for their dominance, Archaea are likely better adapted to low energy flux (Valentine, 2007) and therefore have an advantage over Bacteria in oligotrophic sediments in contrast to eutrophic sediments (Schippers et al., $2005,2012)$. Another explanation is the deposition of archaeal cells from the water column and their preservation in the sediment. Karner et al. (2001) counted pelagic cells of Crenarchaeota, Euryarchaeota, and Bacteria by fluorescence in situ hybridization in the open ocean up to $5000 \mathrm{~m}$ water depth (station in North Pacific subtropical gyre). In their results, the fraction of Crenarchaeota relative to total DNA containing prokaryotes equaled or exceeded 
the bacterial fraction below $1000 \mathrm{~m}$. Further work on the composition of the microbial communities should reveal their origin and function in the oligotrophic subsurface sediments.

\section{Acknowledgments}

This work is supported by the German Research Foundation (DFG) priority program 527 IODP/ODP grant SCHI 535/7 to A.S. The DFG also provided ship time and financial support for the Cruises MSM 11/1 and MSM 20/5 with the German R/V Maria S. Merian. We thank the chiefs Wolfgang Bach, Katrina Edwards, and Heiner Villinger, the crew, and the science party members, especially Anna Blazejak and Beth N. Orcutt for their efforts during sampling.

\section{References}

D’Hondt, S., Jørgensen, B.B., Miller, D.J., Batzke, A., Blake, R., Cragg, B.A., Cypionka, H., Dickens, G.R., Ferdelman, T., Hinrichs, K.-U., Holm, N.G., Mitterer, R., Spivack, A., Wang, G., Bekins, B., Engelen, B., Ford, K., Gettemy, G., Rutherford, S.D., Sass, H., Skilbeck, C.G., Aiello, I.W., Guerin, G., House, C.H., Inagaki, F., Meister, P., Naehr, T., Niitsuma, S., Parkes, R.J., Schippers, A., Smith, D.C., Teske, A., Wiegel, J., Naranjo Padillo, C., and Solis Acosta, J.L., 2004. Distributions of microbial activities in deep subseafloor sediments. Science, 306(5705):22162221. doi:10.1126/science.1101155

Durbin, A.M., and Teske, A., 2012. Archaea in organic-lean and organic-rich marine subsurface sediments: an environmental gradient reflected in distinct phylogenetic lineages. Front. Extreme Microbiol., 3:168. doi:10.3389/ fmicb.2012.00168

Edwards, K.J., Becker, K., and Colwell, F., 2012. The deep, dark energy biosphere: intraterrestrial life on Earth. Annu. Rev. Earth Planet. Sci., 40(1):551-568. doi:10.1146/annurev-earth-042711-105500

Hoehler, T.M., and Jørgensen, B.B., 2013. Microbial life under extreme energy limitation. Nat. Rev. Microbiol., 11(2):83-94. doi:10.1038/nrmicro2939

Kallmeyer, J., Pockalny, R., Adhikari, R.R., Smith, D.C., and D'Hondt, S., 2012. Global distribution of microbial abundance and biomass in subseafloor sediment. Proc. Natl. Acad. Sci. U. S. A., 109(40):16213-16216. doi:10.1073/pnas.1203849109

Karner, M.B., DeLong, E.F., and Karl, D.M., 2001. Archaeal dominance in the mesopelagic zone of the Pacific Ocean. Nature (London, U. K.), 409(6819):507-510. doi:10.1038/35054051

Kates, M., Yengoyan, L.S., and Sastry, P.S., 1965. A diether analog of phosphatidyl glycerophosphate in Halobacterium cutirubrum. Biochim. Biophys. Acta, Lipids Lipid
Metab., 98(2):252-268. doi:10.1016/00052760(65)90119-0

Lomstein, B.A., Langerhuus, A.T., D’Hondt, S., Jørgensen, B.B., and Spivack, A., 2012. Endospore abundance, microbial growth and necromass turnover in deep subseafloor sediment. Nature (London, U. K.), 484(7392):101-104. doi:10.1038/nature10905

Lunau, M., Lemke, A., Walther, K., Martens-Habbena, W., and Simon, M., 2005. An improved method for counting bacteria from sediments and turbid environments by epifluorescence microscopy. Environ. Microbiol., 7(7):961-968. doi:10.1111/j.1462-2920.2005.00767.x

Nadkarni, M.A., Martin, F.E., Jacques, N.A., and Hunter, N., 2002. Determination of bacterial load by real-time PCR using a broad-range (universal) probe and primers set. Microbiology, 148:257-266. http://mic.sgmjournals.org/content/148/1/257.full.pdf

Parkes, R.J., Cragg, B.A., Bale, S.J., Getliff, J.M., Goodman, K., Rochelle, P.A., Fry, J.C., Weightman, A.J., and Harvey, S.M., 1994. Deep bacterial biosphere in Pacific Ocean sediments. Nature (London, U. K.), 371(6496):410-413. doi:10.1038/371410a0

Røy, H., Kallmeyer, J., Adhikari, R.R., Pockalny, R., Jørgensen, B.B., and D'Hondt, S., 2012. Aerobic microbial respiration in 86-million-year-old deep-sea red clay. Science, 336(6083):922-925. doi:10.1126/science.1219424

Schippers, A., Kock, D., Höft, C., Köweker, G., and Siegert, M., 2012. Quantification of microbial communities in subsurface marine sediments of the Black Sea and off Namibia. Front. Extreme Microbiol., 3:16. doi:10.3389/ fmicb.2012.00016

Schippers, A., Neretin, L.N., Kallmeyer, J., Ferdelman, T.G., Cragg, B.A., Parkes R.J., and Jørgensen, B.B., 2005. Prokaryotic cells of the deep sub-seafloor biosphere identified as living bacteria. Nature (London, U. K.), 433(7028):861-864. doi:10.1038/nature03302

Takai, K., and Horikoshi, K., 2000. Rapid detection and quantification of members of the archaeal community by quantitative PCR using fluorogenic probes. Appl. Environ. Microbiol., 66(11):5066-5072. doi:10.1128/ AEM.66.11.5066-5072.2000

Valentine, D.L., 2007. Adaptations to energy stress dictate the ecology and evolution of the archaea. Nat. Rev. Microbiol., 5(4):316-323. doi:10.1038/nrmicro1619

Webster, G., Newberry, C.J., Fry, J.C., and Weightman, A.J., 2003. Assessment of bacterial community structure in the deep sub-seafloor biosphere by $16 \mathrm{~S}$ rDNA-based techniques: a cautionary tale. J. Microbiol. Methods, 55(1):155-164. doi:10.1016/S0167-7012(03)00140-4

Weinbauer, M.G., Beckmann, C., and Höfle, M.G., 1998. Utility of green fluorescent nucleic acid dyes and aluminium oxide membrane filters for rapid epifluorescence enumeration of soil and sediment bacteria. Appl. Environ. Microbiol., 64(12):5000-5003. http:// aem.asm.org/cgi/content/abstract/64/12/5000 
Ziebis, W., McManus, J., Ferdelman, T., Schmidt-Schierhorn, F., Bach, W., Muratli, J., Edwards, K.J., and Villinger, H., 2012. Interstitial fluid chemistry of sediments underlying the North Atlantic gyre and the influence of subsurface fluid flow. Earth Planet. Sci. Lett., 323324:79-91. doi:10.1016/j.eps1.2012.01.018
Initial receipt: 24 January 2013

Acceptance: 2 May 2013

Publication: 28 June 2013

MS 336-201 
Figure F1. qPCR analysis of sterilized North Pond sediments spiked with $10^{6}$ cells/g of different species. Black = total cell counts for comparison, blue = cell numbers with extraction of DNA after Webster et al. (2003) without acid treatment, yellow $=$ cell numbers with $\mathrm{HI}$ treatment, red $=$ cell numbers with $\mathrm{HCl}$ treatment. $16 \mathrm{~S}$ rRNA gene copy numbers per cell used for calculation of cell numbers: Escherichia coli $=5$, Bacillus subtilis $=10$, Methanohalobium evestigatum $=1.5$.

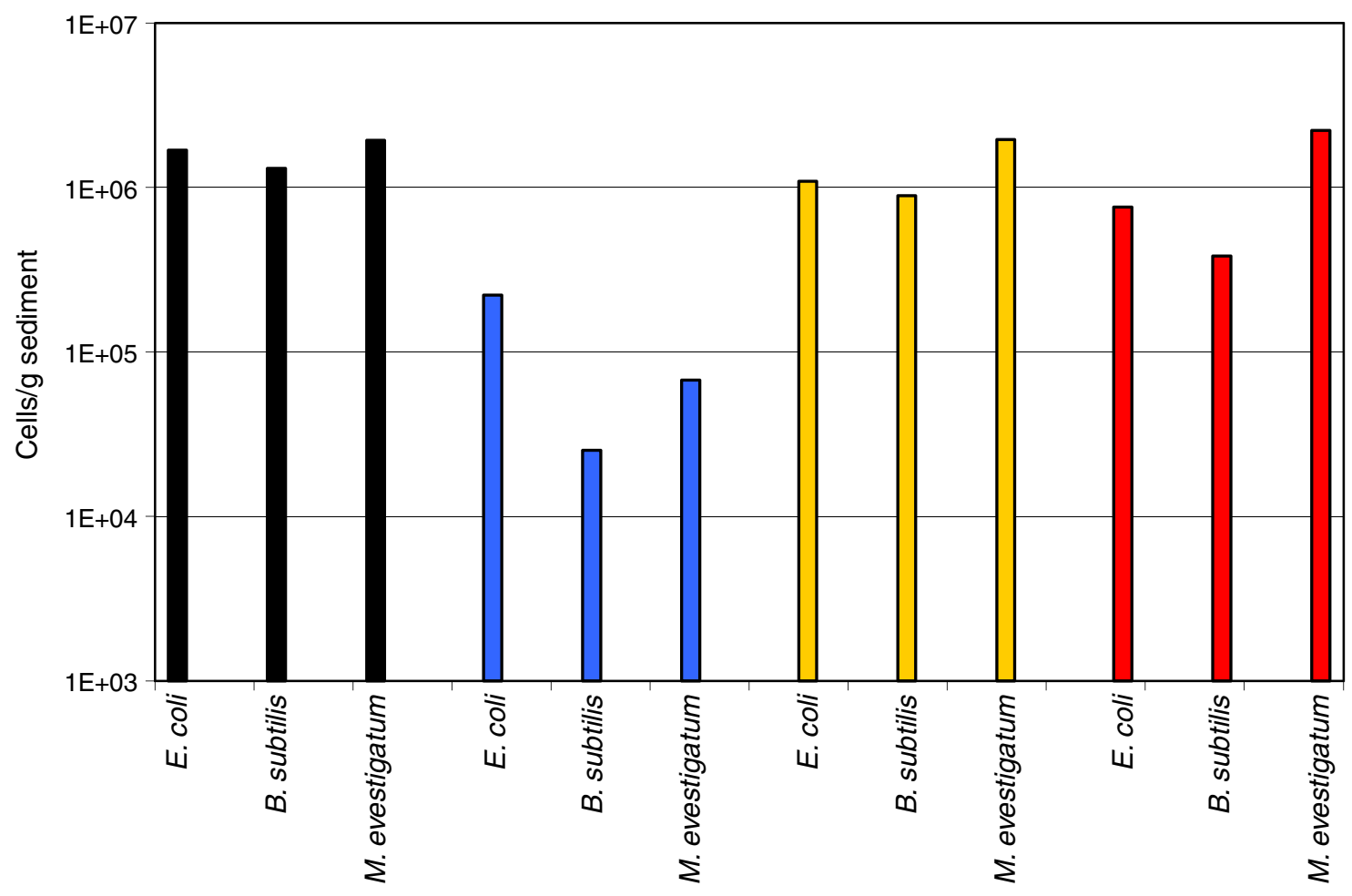


Figure F2. Scanning electron microscopy images of a North Pond sediment sample (A) before and (B) after acid treatment. On A, residual skeletons of diatoms and foraminifera can be seen; on B, the skeletons disappeared.

A

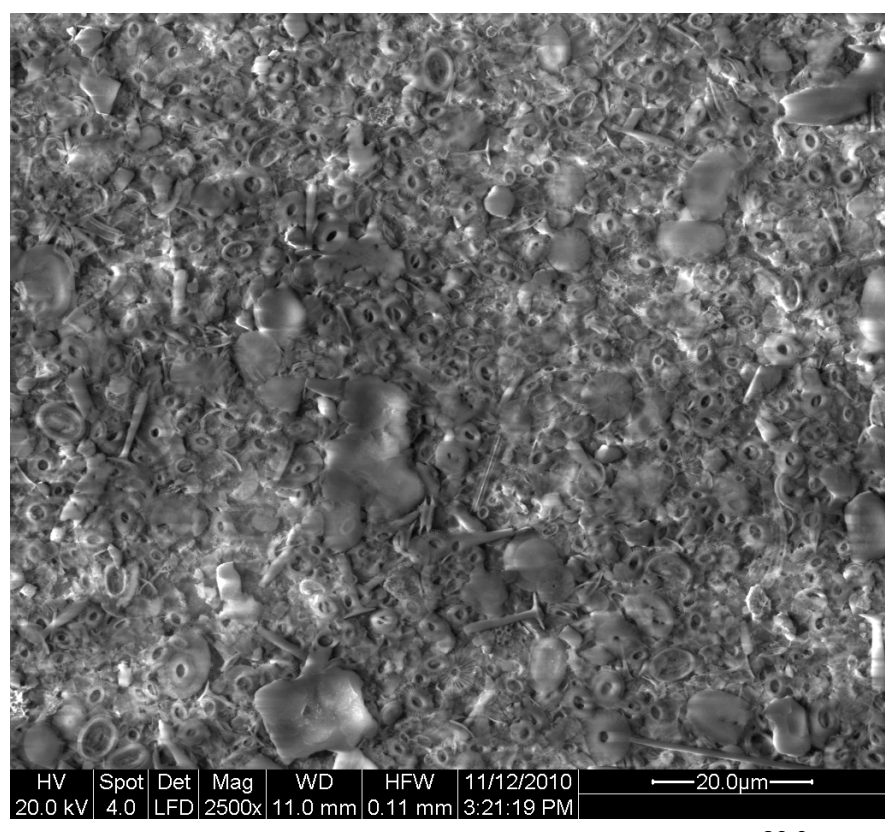

B

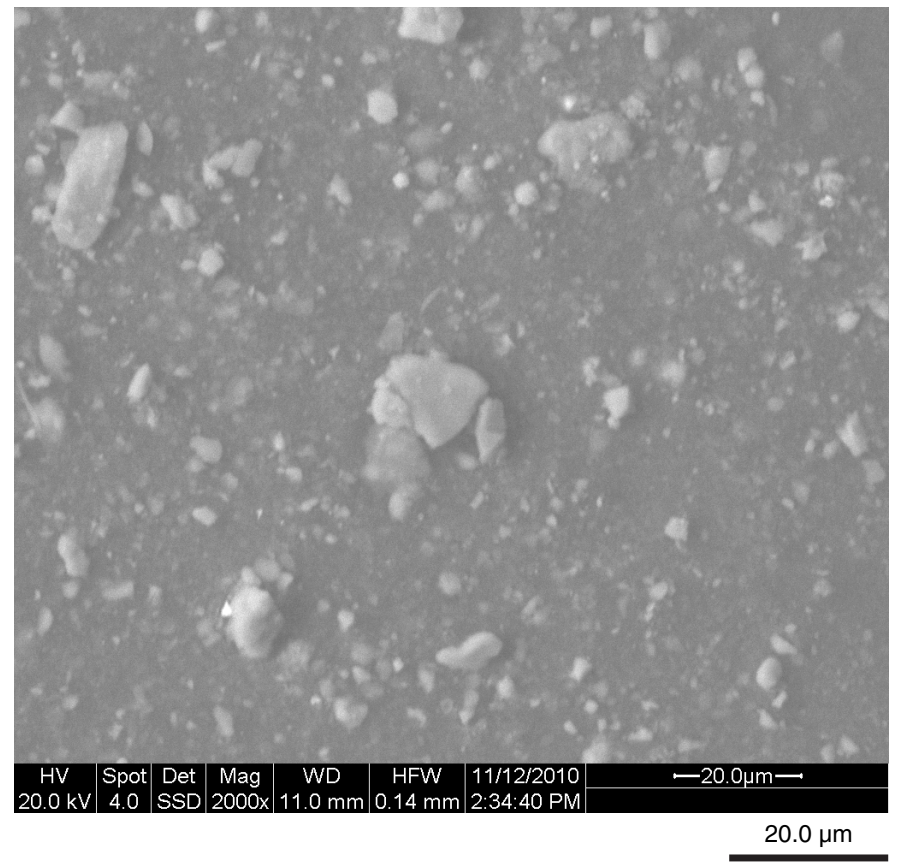


Figure F3. (A) Total cell counts and (B) qPCR abundance of Bacteria and Archaea in organic-lean, oligotrophic, and oxic North Pond subsurface marine sediments (sampling sites Geob 13501, 13502, 13504, 13507, 13510, 13512 [Ziebis et al., 2012]). Near-surface samples taken with push cores (upper $15 \mathrm{cmbsf}$ ) were only analyzed by qPCR.
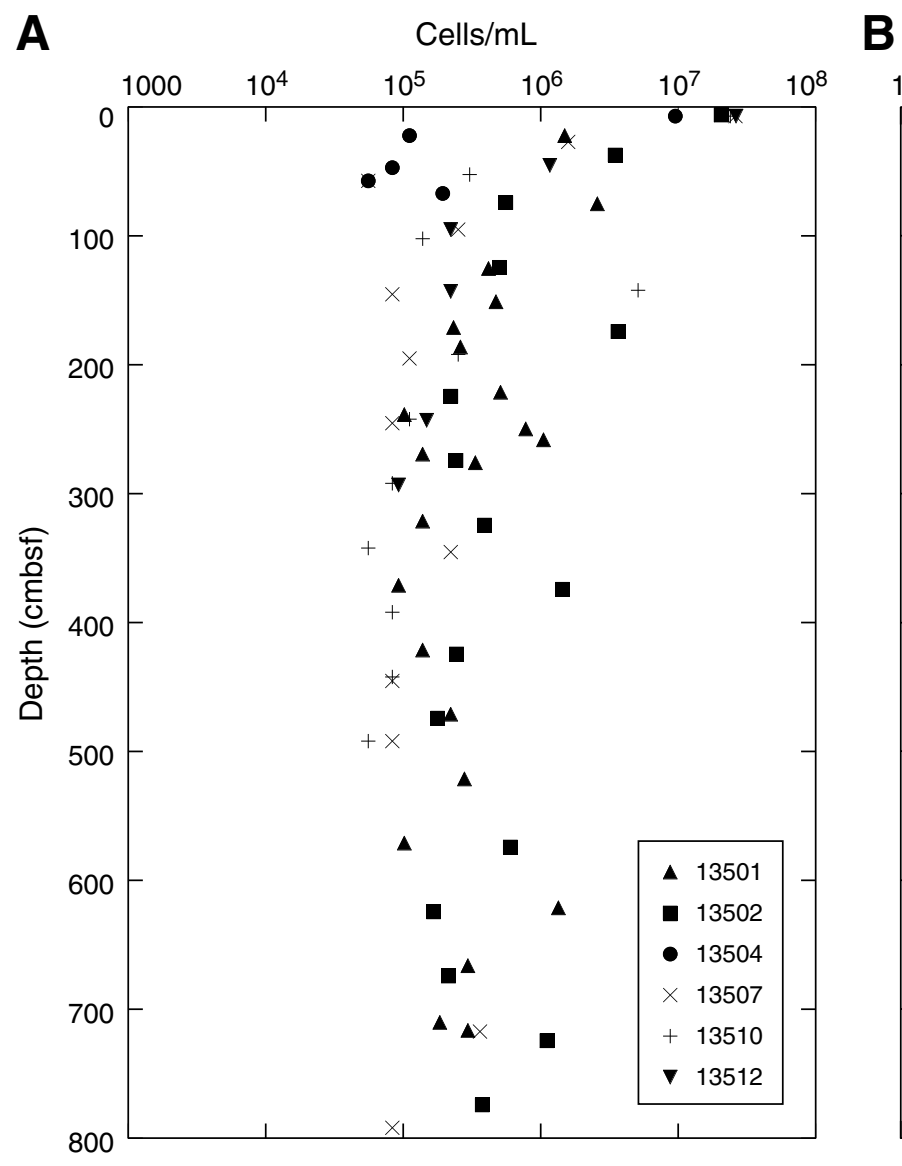

B Cells $/ \mathrm{mL}$

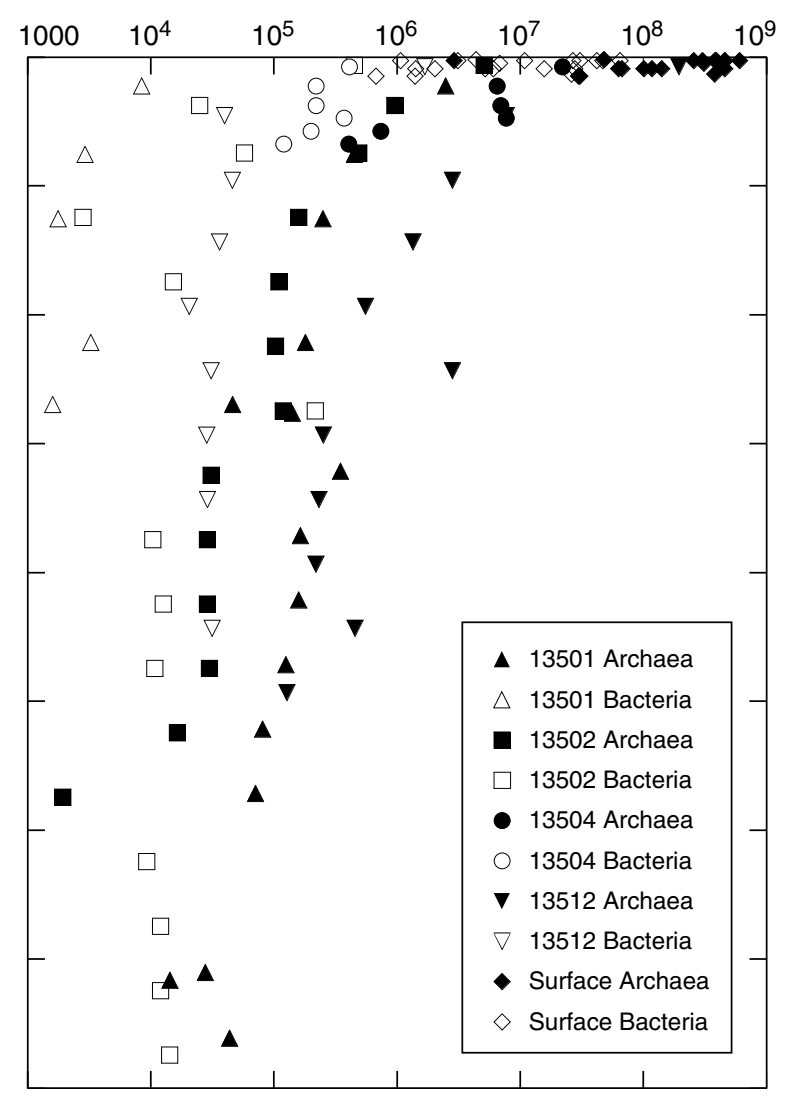

